\title{
Deregulation in Indonesia: Two Steps Forward, One Step Back
}

\author{
George Fane
}

I

$\mathrm{N}$ the late 1970 s and early 1980s, Indonesia's economic policy became increasingly inward-looking as the government pursued a strategy of import substitution. This strategy was reversed in the mid-1980s, and during the past decade the government has liberalised direct controls on investment and greatly reduced both tariffs and import licensing requirements. But despite the clear overall trend, not all economic policies have been moving in the same deregulatory direction. In particular, a new approach to industrial policy, which was announced in President Soeharto's 1995 state address, has the potential to be highly interventionist. Although its details remain vague, early indications suggest that it will be implemented by local content schemes, special tax exemptions, and other non-tariff measures (NTMs).

This article describes the overall trend towards deregulation, discusses why it was adopted, and cites some of the major examples of policy changes in the opposite direction.

\section{Regulation, Deregulation and the Oil Boom}

When it acquired power in 1966, President Soeharto's 'New Order' regime was confronted by the chaos of hyperinflation, multiple exchange rates, and direct controls left behind by President Sukarno. 'The new regime speedily introduced a macroeconomic stabilisation program and then began liberalising Indonesia's trade and investment policies. One of the most notable features of Indonesia's economic policies throughout the whole period since 1970 has been the openness of its capital account. An even earlier indication of the new regime's policy stance was its introduction, in 1967, of a law which guaranteed foreign investors the right to repatriate both capital and profits.

However, economic policy became increasingly inward-looking in the wake of the commodity boom of the early 1970s and the oil price shocks of 1973-74 and 1979-80, which tripled the ratio of Indonesia's export prices to its import prices. In the period from the early 1970s to the mid-1980s, the government taxed or banned some traditional exports, pursued self-sufficiency in rice, and used oil revenues to set up import-

\footnotetext{
${ }^{1}$ The beginning of the New Order period is usually placed at March 1966, even though Sukarno nominally remained president until March 1967.

George Fane is Senior Fellow in the Research School of Pacific and Asian Studies at The Australian National University.
} 
substituting manufacturing industries, which it then protected. In 1974, it ended the relatively unrestricted access which foreign investors had been given in $1967 \mathrm{by}$ closing all sectors to new foreign investment, with the exception of those on a restrictive positive list (Hill, 1988). In addition to the indirect taxation of all export sectors which is effected by protection of import-substituting industries, several traditional export sectors were directly taxed by trade restrictions introduced in the early and mic-1980s. Bans on log exports were introduced in stages during the 1980s, and all log exports were banned after 1985; export bans were extended to raw rattan, and then to semiprocessed rattan. The bans on log exports provided plywood manufacturers with very high effective protection and contributed to the rapid growth in exports of manufactures since the mid-1980s. Exports of vegetable oils, several spices, coffee, and some grades of rubber were also subject to licensing. In the case of crude palm oil, domestic users were protected both by a tax on exports and by an allocation scheme which forced growers to supply domestic refineries with part of their output at low, controlled prices.

After 1982, the dollar price of oil began to decline gradually, and in $1986-87$ it fell abruptly from US\$28 to $\$ 10$ per barrel. This fall wiped out the real gains to Indonesia from the second oil price shock, but not those from the first. In contrast to what happened in some oil-exporting developing countries, such as Mexico and Nigeria, the Indonesian government responded by promptly cutting its own spending and devaluing its currency. In addition to the fall in oil prices, there were two adverse shocks to Indonesia's intertemporal terms of trade in 1982-86: world real interest rates rose, and the appreciation of the yen raised the value of Indonesia's debts relative to the prices of its net exports.

During this period, several major reforms were introduced, beginning with reforms to domestic economic policies. In 1983 the government relaxed bank lending and interest rate controls. The tax system was also modernised between 1983 and 1986; a value-added tax was introduced, and the practice of granting holidays from company tax to new investment projects was ended. But external policy remained unreformed: the import substitution strategy continued to be pursued actively, and import licensing was greatly extended between 1982 and 1985 .

From 1985 onwards, however, international trade policy was liberalised Under the banner of promoting non-oil exports, the government embarked on a series of reform packages which reduced tariffs and non-tariff barriers (NTBs); relaxed controls on foreign and domestic investment; and continued the deregulation of the financial sector. There were major tariff cuts in 1985; and in the same year most customs functions were transferred from the Indonesian Customs Service to an international inspection company, SGS of Switzerland. The process of removing NTBs on imports began in 1986, and in the same year the former system for providing exporters with duty-free inputs was revamped and extended. 


\section{Table 1}

\section{Effective rates of protection (\%), 1987-2003}

\begin{tabular}{|l|c|c|c|c|}
\hline & 1987 & 1994 & 1995 & 2003 \\
\hline Sectors & & & & \\
\hline Manufacturing (excluding oil \& gas) & 86 & 29 & 24 & 16 \\
\hline Manufacturing (including oil \& gas) & 48 & 23 & 20 & 13 \\
\hline Agriculture & 24 & 14 & 12 & 9 \\
\hline & & & & \\
\hline All tradable sectors & 18 & 9 & 8 & 4 \\
\hline & & & & \\
\hline Memo items $^{\text {Anti-trade bias }}$ & & & & \\
\hline Nominal wage effect $^{\mathrm{c}}$ & 52 & 33 & 28 & 20 \\
\hline
\end{tabular}

\section{Notes}

The estimates for 1987 and 1995 are from Fane and Condon (1995). They measure ERPs just before the reform package of December 1987 and just after the reform package of May 1995. The estimates for 1994 and 2003 apply the same methodology. The 1994 estimates measure protection just after the package of June 1994. The ERPs for 2003 use the future tariff cuts announced in the May 1995 package to be implemented by 2003.

${ }^{\mathrm{b}}$ The anti-trade bias (ATB) is defined by: $1+$ ATB $=\left(1+g^{m}\right) /\left(1+g^{\theta}\right)$, where $g^{m}$ and $g^{\theta}$ denote, respectively, the average ERPs in all import-competing and all export-competing sectors.

'The wage effect is the amount by which the whole system of trade policies is estimated to have raised the money wage, at a given exchange rate. A measure of the real protection to each sector is the excess of its ERP over the wage effect.

According to the estimates in Table 1, the average effective rate of protection (ERP) for the whole manufacturing sector, excluding natural gas and oil refining, fell from 86 per cent in 1987 to 24 per cent in 1995. Over the same period, the average ERP for agriculture fell from 24 per cent to 12 per cent, and the anti-trade bias of government policy (which is a measure of the combined average rates of import duties and export taxes) fell from 52 per cent to 28 per cent. ${ }^{2}$ Since there was probably more 'water' in the tariffs in 1987 than in 1995, the measured falls in protection probably overstate the true falls; however, there is little doubt that the true falls have been very substantial. Not only were the levels of trade barriers sharply reduced, but the method of providing protection was made more transparent by replacing many NTBs with tariffs. The industries whose outputs were subject to 'restrictive' NTBs are estimated to have accounted for 44 per cent of total value added in all tradable industries in 1986; by 1995 this proportion had fallen to 23 per cent. ${ }^{3}$ The switch from NTBs to

\footnotetext{
'Anti-trade bias' is the average ERP for all import-substituting industries, relative to that for all exportcompeting industries. A formal definition is given in Table 1, note (b).

3

Fane and Condon (1995, Table 4). 'Restrictive NTBs' are defined to include both import and export NTBs. All export NTBs (other than the need for a general exporters' permit) are regarded as restric-
} 
tariffs was much more pronounced in manufacturing than in agriculture: in manufacturing, excluding natural gas and oil refining, the estimated NTB coverage of value added fell from 77 per cent in 1986 to 17 per cent in 1995; in agriculture, the corresponding fall was from 67 per cent to 48 per cent.

A milestone in the process of relaxing controls on foreign and domestic investment was the replacement, in 1989, of the positive list of prionity sectors open for investment by a less restrictive negative list of closed sectors. Investment licensing was further liberalised in the packages of 1992-94. Investments still have to be approved by the Investment Co-ordination Board but, following the package of May 1994, the former requirement that foreign investors gradually transfer ownership to Indonesian companies has almost disappeared. Most sectors are now open to foreign investment, but some important restrictions remain, including the closure of nine service industries to foreign investors, and of many agricultural and handicrafts sectors to all medium and large firms, both domestic and foreign.

\section{The Political Economy of Regulation and Deregulation}

One factor which contributed to Indonesia's movement away from an inward-looking import substitution strategy towards deregulation and trade liberalisation in the mid1980s was the growing worldwide belief that reliance on market forces has usually been more successful than detailed economic interventions by governments. Economic policy in the fast growing East Asian countries has clearly not been laissez faire, but it has been less interventionist, and very much more open to international competition, than economic policy in Latin America or Africa. East Asia's success was therefore a powerful influence on Indonesia's decision to pursue deregulation in general, and trade liberalisation in particular.

A second explanation for Indonesia's change of strategy in the mid-1980s was President Soeharto's absolute authority, together with his confidence in his economic advisers, and their broad support for macroeconomic stability and economic deregulation. But while this can help explain the consistent pursuit of orthodox monetary and fiscal policies throughout the New Order period, it cannot by itself explain the change of direction on deregulation: if the authority and high quality of Indonesia's economic decision-makers enabled them not merely to resist the pressures to restrict imports when oil prices fell, but actually to embark on widespread deregulation and trade liberalisation, why had Indonesia been following a strategy of inward-oriented import substitution since the early 1970s? A possible answer is that Soeharto bothered with economic advisers only in times of economic crisis; but if he had such confidence in them, it seems odd that he did not always take their advice on economic questions.

A third possibility is that the three adverse terms-of-trade shocks in the period 1982-86 — the fall in oil prices, the rise in interest rates and the appreciation of the yen - may have contributed to Indonesia's adoption of deregulation. The support-

tive. In the case of NTBs on imports, the general importer (IU), importer-producer (PI) and sole agent (AT) licensing requirements are not counted as restictive. 
ers of deregulation have summarised this hypothesis thus: 'good times mean bad policies; bad times mean good policies'. Indonesia's own reduced ability to finance investment at the rate needed to maintain the rate of growth of GDP and of employment opportunities helps to explain why an open capital account was maintained, and why controls on foreign direct investment were liberalised in the late 1980 s and early 1990s. But for the 'bad times-good policies' hypothesis to be fully satisfactory, it must explain why adverse terms-of-trade shocks led to trade liberalisation in Indonesia, whereas in other countries they have sometimes led to the imposition of exchange controls and import licensing.

One part of the explanation is that the fall in oil prices raised the profitability of all the other tradable sectors by depressing the prices of non-tradables relative to the prices of these other tradable sectors. This made it possible for the government to reduce the protection granted to manufacturing without reducing its profitability on average; despite reduced protection, the manufacturing sector has therefore been able to grow very rapidly since the early 1980 s. A second part of the explanation relies on the distinction between adverse terms of trade shocks and adverse fiscal shocks. These two types of shocks need not go together, but they did in Indonesia, where oil was both Indonesia's main export and the government's main source of revenue, and where most foreign debt was also public debt. Although adverse terms-of-trade shocks increase pressures on governments to restrict imports, adverse fiscal shocks encourage the numerous forms of deregulation which involve the reduction of subsidies, whether explicit or hidden. To ensure that fiscal stringency resulted in reduced subsidies rather than rapid inflation, it was important that Indonesia did not balance its budget at the margin by resorting to inflationary finance; this was ensured by the fear of hyperinflation inherited from the experience of the mid-1960s, and by the longstanding convention that any deficit in the budget must be financed by foreign borrowing.

The importance of adverse fiscal shocks in inducing policy reform in Indonesia in the early 1980s has been emphasised by Robison (1987:31-4). Among the deregulatory reforms of the mid-1980s which can be attributed to fiscal stringency were the postponement, or cancellation, in May 1983 of US\$20 billion of public-sector investment projects, and reductions in the explicit subsidies to food, fuel, and fertilisers. The government's reduced ability to afford subsidies also reinforced the incentives to switch from NTBs to tariffs and from tariffs to consumption taxes. One of the most familiar arguments to justify replacing NTBs by tariffs, is that this would generate revenue for the government, which would otherwise accrue to the holders of import licences. A similar logic applies to the switch from import duties to consumption taxes, such as the VAT which Indonesia introduced in 1986: since an import duty is equivalent to a consumption tax, part of whose revenue is used up in subsidising production at the same rate, a switch from a tariff to a consumption tax allows the gov-

\footnotetext{
4 In Indonesia, this requirement is referred to as the 'balanced budget' requirement, since net foreign bonrowing is treated, under its unconventional accounting definitions, as being part of government revenue.
} 
ernment to increase its revenue, or reduce the tax rate, or both. The reform of the financial sector had a similar origin. In the oil boom period, the state banks were heavily involved in channelling subsidised loans from the central bank, Bank Indonesia, into various special programs, such as the Bimas scheme to help rice growers achieve self-sufficiency. The fiscal deterioration of the early 1980 s provided the stimulus for cutting back these subsidised lending schemes, which had proved far more expensive than expected because of high default rates. The need to allow nonsubsidised bank lending to replace these failed schemes provided the impetus for the 1983 banking deregulation.

Fiscal shocks also directly affected the relative political influence of two of the many competing groups of advisers to the President: the 'technocrats' and the 'economic nationalists'. The technocrats tend to favour reliance on market forces, and many of them are professional economists; they have normally dominated the Ministry of Finance and the National Plaming Agency, and have had a substantial influence in Bank Indonesia. The World Bank has used its influence directly on the side of the technocrats, and its resources and technical expertise have also played an indirect role by helping them to make their case in a convincing way.

The economic nationalists, meanwhile, comprise several sub-groups, the most prominent of which are the 'engineers' led by the Minister for Research and Technology, Dr BJ. Habibie. The engineers seek to promote large-scale, capital-intensive, projects, using advanced technologies, in industries such as aeronautics, shipbuilding, steel, fertilisers, and petrochemicals. They believe that these enterprises should often be state-owned, and may need direct government subsidises as well as protection from imports. A second sub-group of nationalists is composed of the advocates of selfsufficiency in food in general and rice in particular. The business conglomerates also intermittently support economic nationalism when it suits them. In addition to Habibie's own department, the economic nationalists have dominated the national oil company (Pertamina), the government agency responsible for food procurement and marketing (Bulog), and the Ministry of Industry.

Adverse fiscal shocks, as well as affecting the ability of the government to subsidise the economic nationalists' favoured projects, have raised the relative influence of the technocrats, for two reasons. First, the fall in government revenue and the increase in the burden of the government's foreign debts increased the influence of the World Bank, whose conditional willingness to extend new loans to Indonesia was important both directly and as a signal to other potential forcign lenders. Second, the fall in oil prices diminished the influence of Pertamina by reducing its contribution to government revenue, and raised that of the Ministry of Finance, whose tax reforms, designed by technocrats and like-minded foreign advisers, helped to make up for lost oil revenue.

\section{New Regulations and Presidential Patronage}

Although deregulation has been the dominant feature of economic policy during the last decade, there have also been important examples of new regulations being introduced. One area which provides several examples of newly introduced regulations is 
the labour market: large increases in minimum real wages were legislated in 1993 and 1994, and in 1993 a workers' social security scheme was introduced, which requires all firms with more than ten employees to give them free health care, retirement benefits, life-insurance, and workers' compensation insurance. ${ }^{5}$ The impact of these labour market regulations has so far been substantially limited by the difficulties of enforcing them.

Other examples of new regulations include the growth of prudential controls on the banking sector; the 1995 closure to potential new entrants, at least temporarily, of the non-bank financial sector (Jakarta Post, 23 December 1995); and the transfer of customs inspection duties from SGS of Switzerland to an Indonesian inspection company. Capital mobility was somewhat restricted in 1991 by the re-imposition of limits on shorter-term foreign borrowing by banks, and by the establishment of a committee whose approval has to be obtained by investors wishing to borrow from abroad to finance projects which are comected in any way with state enterprises, including even projects which borrow from state banks.

There have been many examples of policies which have favoured individual firms, rather than whole industries. Such interventions have been both a cause and a consequence of the importance of patronage in Indonesia: to influence industrial policy, as well as to minimise routine bureaucratic delays, major business ventures often take on one of the President's family or associates as a board member or shareholder. These well-connected enterprises have received some spectacular privileges: examples from the 1990s include the national car plan (discussed below); the setting up of a heavily protected soybean crushing plant; the creation of a private monopoly over the trade in cloves between the growers and the manufacturers of clove-scented cigarettes; the creation of a temporary private monopoly over inter-island exports of oranges from West Kalimantan; and the granting of special tariff protection to the giant Chandra Asri petrochemical project. ${ }^{7}$ Like Chandra Asri and like the chosen producer of Indonesia's subsidised national car, the private firms that were granted the monopolies over cloves and oranges were both partly owned by members of the President's family; the soybean crushing plant is controlled by the largest of the Indonesian conglomerates, the Salim group. A scheme which had several features in common with the clove and oranges monopolies was implemented in 1995 by the provincial government in Bali, which granted a company controlled by one of the President's grandsons the right to sell stickers which beer manufacturers were required to fix to all bottles sold in Bali. The manufacturers had to pay 600 rupiahs (about A\$0.33) a bottle, one third of which went to the provincial government and the rest to the President's grand-

\footnotetext{
5 The workers' social security scheme is described and analysed by McLeod (1993). 6 Bank Indonesia Circular, no. 24/38/ULN, 20 November 1991.

${ }^{7}$ The Chandra Asri petrochemical complex in West Java, which produces plastic raw materials, is a joint venture between Japanese and Indonesian investors. It is reported to have cost about US\$2 billion. Production began in 1995 . The two Indonesians with the largest shareholdings are one of the President's sons and a timber tycoon, Mr Prajogo Pangestu.
} 
son's company. Perhaps because this scheme was too transparent, it was abolished in early 1996 (The Australian, 5 February 1996).

\section{Prospects for Further Trade and Investment Liberalisation}

Substantial progress on reducing tariffs and liberalising investment regulations has been made since 1994. The most important of these reforms came in the May 1995 package, which was presented as a 'dowmpayment' on Indonesia's commitments under the Bogor declaration to Asia Pacific Economic Co-operation (APEC). It substantially reduced tariffs and is the first Indonesian package to announce a schedule of future tariff reductions. These announced reductions cover the period 1995-2003, and will extend to all countries the tariff cuts which Indonesia was already committed to giving to its partners in the Association of South East Asian Nations (ASEAN), under the ASEAN Free Trade Area (AFTA) agreement.

After May 1995, the only imported items with total import duty rates in excess of 40 per cent were motor vehicles and components, and alcoholic beverages. The highest rates for these items were 200 per cent on fully assembled passenger vehicles, and up to 170 per cent on some alcoholic beverages. If the announced schedule of tariff reductions is adhered to, the maximum total duty rates in 2003 for vehicles and components and alcoholic beverages will be 100 per cent and 20 per cent, respectively; and the maximum duty rate on items outside these two sectors will be 15 per cent. However, many manufacturing sectors will receive much higher effective rates of protection, since the rates of duty on inputs will generally continue to be less than those on outputs. ${ }^{8}$ Table 1 provides a comparison between the unilateral trade liberalisations made in the period 1987-94, and the actual and proposed liberalisations introduced in May 1995.

Despite its support for APEC's non-binding commitments to free trade, and the very substantial trade liberalisations which have been made unilaterally since the mid1980 s, Indonesia managed to make few important trade liberalisation commitments in the Uruguay Round. The most important of these commitments were promises to remove NTBs which restricted imports of some industrial items; to phase out the local content scheme for dairy products over a decade; and to phase out the local content scheme for soybean meal over three years. The many new 'tariff bindings' which it made in the Round limited its right to increase tariffs above the currently applied rates, but in no instance was the new bound rate below the currently applied rate. And, apart from the local content schemes for milk and soybean meal, all the major NTBs on agricultural products will be unaffected by the nominal requirement of Article 4.2 of the Uruguay Round Agreement on Agriculture that countries must remove 'quantitative import restrictions' and 'non-tariff measures maintained through state trading companies [STCs]'. 'The reason is that Indonesia, like other developing countries, has been allowed to maintain the fiction that the sales and purchases of its STCs

\footnotetext{
${ }^{8}$ Based on the estimates underlying Table 1, the two broadly defined groups of sectors with the highest average ERPs in 2003 will be engineering and wood products. The estimated ERPs for these groups of sectors will be 74 per cent and 38 per cent, respectively.
} 
- in this case, Bulog — are made 'solely in accordance with commercial considerations', and that Bulog's import monopolies, which have been used, inter alia, to ban imports of rice for long periods, are therefore not quantitative import restrictions, but purely commercial activities, sanctioned by s.1(b) of Article XVII of the original General Agreement on Tariffs and Trade! A further indication of Indonesia's continuing reluctance to dismantle its controls on agricultural trade was given at the December 1995 ASEAN summit, when Indonesia was responsible for postponing until 2003, and perhaps 2010 , a proposed extension of the AFTA agreement which would have reduced barriers to trade on 15 agricultural products, including rice and sugar.

\section{A More Interventionist Industry Policy?}

The President's 1995 state address set out a new, and potentially more interventionist, industrial policy, under which vaguely defined 'key' industries will be favoured over others. It is unclear what this policy will mean in practice, but the examples of the petrochemical and vehicle industries, which are discussed below, suggest that it may be implemented by means of local content schemes and selective tax exemptions to protect individual firms.

It has been widely suggested that Indonesia's enthusiastic support for APEC's goal of free trade was responsible for the 1995 decision not to grant the Chandra Asri olefins project the increased tariff protection which it had originally been led to expect. Instead, the government indicated that Chandra Asri would be protected by means of a local content scheme (Soesastro, 1995:25-6). However, in February 1996, the government buttressed the protective arrangements for Chandra Asri by reversing the position it had adopted before the APEC summit in Osaka, imposing instead 20 per cent tariff surcharges on imports competing with Chandra Asri's two main products, ethylene and propylene. The details of the local content scheme remain opaque, and even the imposition of the new tariff surcharges was leaked, rather than formally announced by the government. ${ }^{3}$ Since both products were already subject to 5 per cent tariffs, the total duty on each is now 25 per cent.

Indonesia's recently announced plan to produce a 'national' car provides another indication of what the new industrial policy may involve. On 26 February 1996, Kia Motors of South Korea and Timor Putra Nasional, an Indonesian company controlled by one of the President's sons, ammounced a planned joint venture to build a plant near Jakarta, 30 per cent owned by Kia, to assemble jeeps and two models of sedans from components made in Korea by Kia. Two days later, the Minister for Industry and Trade announced that the Kia-Timor operation had been approved as the producer of Indonesia's national car. As such, it will qualify for two substantial tax privileges: exemption from luxury sales tax, and exemption from tariffs on imported components; one Jakarta economist has estimated these priveleges to be worth US\$1 billion over three years (Australian Füancial Review, 20 March 1996).

\footnotetext{
${ }^{9}$ The surcharge on propylene was revealed in a press release issued in New York by one of Chandra Asri's customers. A copy of the decree imposing the surcharge on ethylene was obtained by the Asian Wall Street.Journal (4 March 1996) and subsequently confirmed by government officials.
} 
The new decrees which set out the national car policy state that the producer must be 100 per cent Indonesian owned, must use an Indonesian brand name, must develop local technology, and must satisfy escalating local-content requirements: 20 per cent local content by the end of the first year, 40 per cent by the end of the second, and 60 per cent by the end of the third. Although these decrees do not refer to KiaTimor, and do not specifically exclude the possibility of more than one national car, the Minister has subsequently announced that Kia-Timor will have a monopoly for at least three years. ${ }^{10}$ In view of the initial announcement that Kia would supply all the components and own 30 per cent of the plant, some ingenuity may be required to find legal formulas to get around the nominal requirement that the national car producer must be 100 per cent Indonesian-owned. Although the new venture has announced plans to set up a plant to produce components in Indonesia, the local-content requirements may also be hard to fulfil; however, considerable administrative discretion will presumably be exercised in measuring and enforcing, or not enforcing, compliance with these requirements.

Like the maintenance of barriers to agricultural trade and the opaque arrangements for protecting Chandra Asri, the national car plan confirms the impression that economic nationalism, often reinforced by presidential patronage, remains a very important influence on economic policy in Indonesia. But since these interventions are of less quantitative importance than the very large reductions in trade and investment barriers which have occurred since the mid-1980s, the title of this article gives a fair summary of Indonesia's achievements and prospects on deregulation.

\section{References}

Fane, G. \& 'T. Condon (1995), 'Trade reform in Indonesia, 1987-1995', mimeo, Australian National University, Canberra.

Hill, H. (1988), Foreign Investment in Indonesia, Oxford University Press, Singapore.

McLeod, R. (1993), 'Workers' social security legislation', ch. 6 in C. Manning \& J. Hardjono (eds), Indo nesia Assessment 1993, Australian National University, Canberra (Political and Social Change Monograph 20).

Robison, R. (1987), 'After the Gold Rush', ch. 2 in R. Robison, K. Hewison \& R. Piggott (eds), Southeast Asia in the 1.980s: the Politics of Economic Crisis, Allen \& Unwin, Sydney.

Soesastro, H. (1995), 'The Economy: A General Review', ch. 2 in C. Barlow (ed.), Indonesia Assessment 1995, Australian National University, Canberra and Institute of Southeast Asian Studies, Singapore.

\section{I am grateful to Ross Garnaut, Hal Hill, Ross McLeod, Chris Manning, and Peter Warr for their suggestions.}

\footnotetext{
${ }^{10}$ Asian Wall Street Joumal, 29 February 1996; Far Eastern Economic Revicw, 14 March 1996; and Australian Financial Review, 6 March 1996.

11

A subsequent presidential decree (4 June 1996), introduced after this article had been completed, announced that the first year's supply of Indonesia's 'national' car can be obtained by importing fully built-up Kia sedans, rebadged as 'Timors', from Korea! (The Australian, 19 June 1996).
} 